\title{
'Could it be mycosis fungoides?': an approach to diagnosing patch stage mycosis fungoides
}

\author{
Nathan T. Harvey ${ }^{1,2}$ - Dominic V. Spagnolo ${ }^{1,2}$ • Benjamin A. Wood ${ }^{1,2}$
}

Received: 19 May 2015 / Accepted: 29 May 2015 / Published online: 23 June 2015

(C) Springer-Verlag Berlin Heidelberg 2015

\begin{abstract}
Mycosis fungoides (MF) is the most common primary cutaneous $\mathrm{T}$ cell lymphoma, which is characterised in its early stages by epidermotropism of small to medium-sized $\mathrm{T}$ lymphocytes with cerebriform nuclei. Originally described by Alibert in 1806, MF is classically a disease of adults, although children and adolescents can be affected, and it typically has a protracted, indolent course. Routine dermatopathology practice involves many biopsies submitted with a clinical query regarding the possibility of MF. These are not always straightforward, as the histological features can be variable and are not always readily distinguishable from several other clinical differential diagnoses. Whilst modern molecular testing modalities can assist, even these do not always enable a definitive diagnosis of MF in its early stages. We have reviewed the histopathological features of early MF and currently recognised subtypes and the role of immunohistochemistry and emerging molecular techniques in the diagnosis of this condition. We also outline our approach to a biopsy where the question of 'Could it be MF?' has been proposed.
\end{abstract}

Keywords Mycosis fungoides · Dermatopathology · Cutaneous T cell lymphoma

Nathan T. Harvey

nathan.harvey@health.wa.gov.au

1 Department of Anatomical Pathology, PathWest Laboratory Medicine WA, QEII Medical Centre, Hospital Ave, Nedlands, WA 6009, Australia

2 School of Pathology and Laboratory Medicine, University of Western Australia, Perth, WA, Australia

\section{Introduction}

Mycosis fungoides (MF) is a primary cutaneous $\mathrm{T}$ cell lymphoma (PCTCL), representing approximately $50 \%$ of all primary cutaneous lymphomas [1]. It is defined histologically by epidermotropism of small- to medium-sized T lymphocytes with cerebriform nuclei. Originally described by Alibert in 1806 [2], MF is typically a disease of adults, although children and adolescents can be affected, and is characterised by a protracted, indolent course. Three clinical phases are recognised, with progression from patches to infiltrated plaques and eventually tumours. However, it is estimated that over $90 \%$ of patients will not progress to tumour stage, and patients with limited disease show a similar survival to the general population $[1,3]$.

Routine dermatopathology practice involves many biopsies submitted with a clinical query regarding the possibility of MF. These are not always straightforward, as the histological features can be variable and are not always readily distinguishable from several other clinical differential diagnoses. Whilst modern molecular testing modalities can assist, even these do not always enable a definitive diagnosis of MF in its early stages. In this review, we outline our approach to this problem.

\section{Clinical context}

MF is divided into three clinical stages (patches, plaques and tumours) which correlate with disease stage and prognosis. Patches are variably sized and erythematous and have a fine scale. The lesions may be hypopigmented (particularly in darker skinned individuals), a yellowish colour may impart a 'xanthomatous' appearance and a wrinkled 'parchment-like' appearance has also been described. Initial lesions often 
develop on the trunk and show a predilection for sunprotected sites (e.g. the buttocks). Classical MF seldom presents initially on the face, genitalia or perianal region [4]. Plaques are slightly elevated or palpably infiltrated lesions with a reddish-brown colour, surface scale and may be focally ulcerated. Tumours may be seen in association with patches or plaques, are often ulcerated and may be quite disfiguring. The 'mushroom-like' appearance of the lesions gave rise to the name [3].

Extracutaneous involvement is rare but may involve the mucosal sites, lymph nodes, spleen, lung and liver. The bone marrow is usually spared [1].

Early MF can be difficult to distinguish clinically from a number of dermatoses and is one of the more common reasons for submission of a biopsy. Amongst the more common clinical differential diagnoses are eczema, psoriasis, superficial fungal infections and drug reactions [4]. The clinical picture may be further confused by other factors such as pruritus, onychodystrophy, acral lesions and erythroderma, all of which can be associated with MF [3]. One characteristic that may be particularly suggestive of MF is the presence of poikiloderma, especially in non-sun-exposed skin. The presence of persistent poikilodermatous patches in these locations is highly suggestive of MF [5]. Plaque stage MF may require distinction from other cutaneous lymphomas which may present with similar clinical lesions. Thus, histological examination often plays a crucial role in establishing the diagnosis.

\section{Histological features of early MF}

Patch or plaque stage lesions of MF are characterised by a proliferation of small- to medium-sized lymphocytes, typically seen in a lichenoid- or band-like arrangement within the superficial dermis. A defining feature is the presence of epidermotropism, which may manifest as collections of lymphocytes within the epidermis ('Pautrier's microabscesses', or more correctly 'Darier's nests') or as linear arrays along the base of the epidermis ('basilar epidermotropism') (Fig. 1a, c). The lesional cells display nuclear irregularity, often described as 'cerebriform' nuclei, and there may be pericellular halos (Fig. 1b, d). While spongiosis may be present, the number of lymphocytes within the epidermis should be disproportionate to the amount of spongiosis in typical cases. A useful clue is the presence of lymphocytes within the epidermis which are larger than their counterparts within the dermis [6-11].

For many years, it was considered impossible to render a definitive histological diagnosis of early MF. In 1979, in the first issue of the American Journal of Dermatopathology, Sanchez and Ackerman first outlined histological criteria for early MF, highlighting the importance of distinguishing the epidermal changes of MF from those of spongiotic inflammatory disorders [9]. They suggested that in MF, intraepidermal lymphocytes were more numerous than in spongiotic disorders, tended to cluster and to be juxtaposed and that they extended up to the granular layer and above. While they noted that an increase in the intercellular spaces between keratinocytes was often seen in MF, they argued that spongiotic microvesiculation was not and its presence indicated a spongiotic dermatosis. The presence of papillary dermal oedema was a similar indication of a spongiotic dermatitis. They also suggested that atypical lymphocytes may not be present in the earliest lesions and thus are not a requirement for diagnosis. Rather, these were more often seen in plaque-stage lesions.

In the decades following this seminal paper, a number of other authors have published similar studies, in an attempt to validate and expand the criteria of Sanchez and Ackerman. In 1988, Nickoloff noted the presence of lymphocytes arranged in a linear fashion along the basal layers of the epidermis as an important criterion [8]. King-Ismael and Ackerman subsequently added the presence of lymphocytes within the epidermis which were larger than those in the dermis and the presence of wiry papillary dermal fibrosis associated with a patchy lichenoid lymphocytic infiltrate [12]. Guitart et al. proposed a scoring system in an attempt to standardise the reporting of these lesions [6]. There have been at least two attempts by international panels to develop diagnostic criteria for early MF. In 2000, Santucci et al. [10] published a retrospective review of biopsies from proven cases of early MF. This study found that the presence of medium to large lymphocytes with convoluted nuclei was the most important histological criterion, including their presence as single cells or small groups within the epidermis or as sheets in the dermis. The proceedings of a workshop conducted in 1999 and published in 2005[5] identified the following as major criteria: the presence of lymphocytes with irregular nuclear contours; the presence of lymphocytes within the epidermis which were larger than those seen in inflammatory dermatoses. Other features, such as haloed lymphocytes, disproportionate epidermotropism or a band-like infiltrate, were found to have less discriminatory value in this study. Both of these international attempts to define diagnostic criteria highlighted the importance of larger lymphocytes with nuclear irregularities; however, as Sanchez and Ackermann noted originally, these cells may not be present in the earliest lesions of MF. Thus, despite these and other studies [11, 13, 14], the diagnosis of early-stage MF has remained one of the more difficult problems in routine dermatopathology.

\section{Subtypes}

\section{Folliculotropic MF}

Folliculotropic MF is a form of the disease that presents with follicular papules and plaques and that may be associated with 


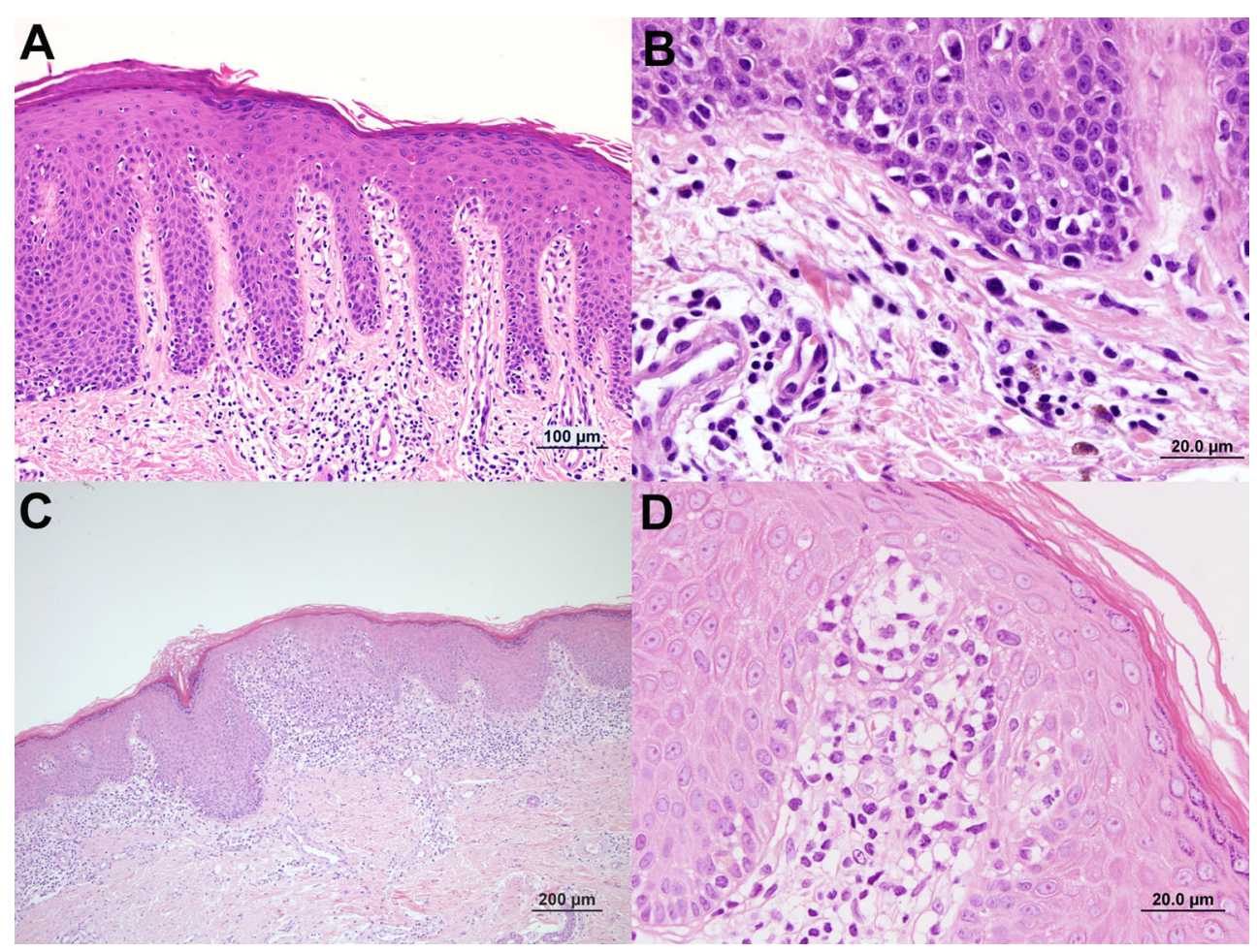

Fig. 1 Typical histological features of early mycosis fungoides. a A low power view shows epidermotropic lymphocytes arranged in a linear array along the basal layer of the epidermis. Many of these show a clear surrounding 'halo'. b Higher power examination reveals nuclear enlargement and hyperchromasia within the epidermotropic lymphocytes. Occasional atypical lymphocytes are also seen in the underlying dermis, where they can be seen admixed with smaller, non-neoplastic lymphocytes. c A low power view of a different case shows a band-like infiltrate of lymphocytes within the upper dermis. Epidermotropic lymphocytes are also present, which in this case form a cluster consistent with a Pautrier's microabscess. d A high power view of this case demonstrates the highly convoluted nuclear outlines seen in the epidermotropic lymphocytes

Several studies have found folliculotropic MF to have a worse prognosis than classical MF, with higher rates of disease progression and lower disease-specific and overall survival rates. On the other hand, at least one study has documented relatively slow disease progression [21]. Response to skin-directed therapy is poor, presumably due to the location of the neoplastic cells within the deeper follicular epithelium $[17,22,23]$.

The relationship between folliculotropic MF and the condition variably termed follicular mucinosis or alopecia mucinosa has been the subject of some debate. Alopecia mucinosa was described in 1957 [24] and is characterised by localised alopecia with the histological finding of mucin deposition within hair follicles. Initially, it was divided into two groups, depending on whether or not there was associated MF. However, subsequent studies showed that this distinction was not reproducible when the proposed criteria were applied strictly [25]. While a number of conditions have been documented to produce mucin deposition within follicles [26], when this occurs without objective evidence of another process, the possibility of folliculotropic MF should at least be considered. Indeed, many authors now regard follicular mucinosis/alopecia mucinosa to be synonymous with folliculotropic MF [19, 25, 27]. 


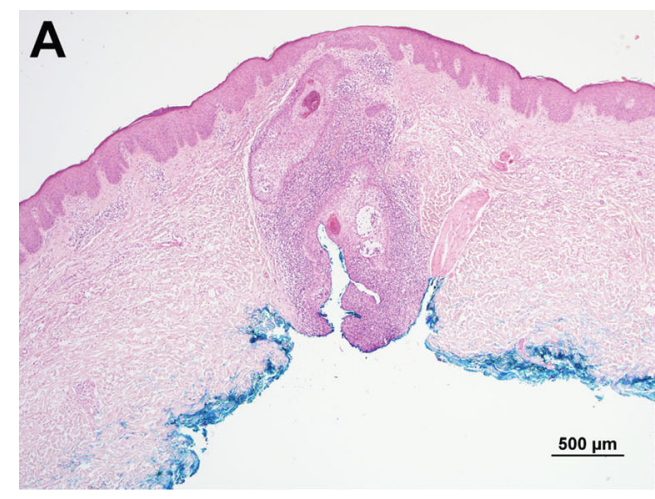

Fig. 2 An example of folliculotropic mycosis fungoides. a Low power examination reveals a perifollicular lymphocytic infiltrate. b At higher power, numerous folliculotropic lymphocytes can be appreciated,

\section{Syringotropic MF}

Related to folliculotropic MF, but rarer, is the variant known as syringotropic MF. The largest series to date of this variant was reported by Pileri et al. [28]. This entity has overlapping clinical features with conventional variants, although solitary lesions seem to be more common and follicular accentuation producing a papular pattern is often seen. Histologically, these lesions are characterised by a dense, often nodular, perieccrine lymphocytic infiltrate. There is prominent syringometaplasia and epitheliotropism, and epidermal involvement is relatively common [28]. Involvement of the hair follicles is also commonly seen, and combined with the findings of Lehman et al. [20], this suggests that both 'adnexotropic' variants of MF are closely related [19].

\section{Pagetoid reticulosis (Woringer-Kolopp type)}

The first description of this condition was in 1939, when Woringer and Kolopp presented a case of a 13-year-old boy with lesions of the forearm, for which they could not offer a diagnosis $[29,30]$. The term pagetoid reticulosis was subsequently coined by Braun-Falco et al. in 1973, when they described a similar adult case [31]. While a number of cases were subsequently reported, the nature of this condition, and its relationship to MF, remained uncertain for many years. Ioannides et al. were the first to suggest that the condition represented a localised form of MF [32], and subsequent studies supported the notion that it represented a $\mathrm{T}$ cell lymphoproliferative disorder [33-35], now considered to be a subtype of MF.

Pagetoid reticulosis presents with one or several, often confluent, scaly, erythematous patches or plaques which are typically located on the extremities. An important criterion for this condition is that the lesions are solitary or at least are localised to one site. The disseminated variant, presenting with generalised lesions of 'pagetoid reticulosis'

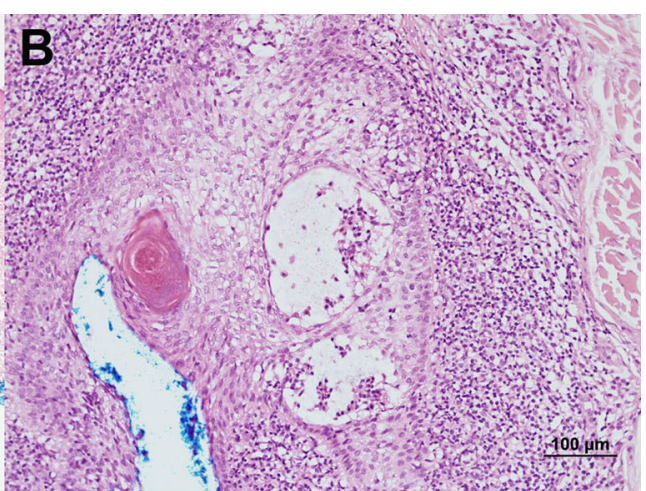

including formation of intra-epithelial collections analogous to Pautrier's microabscesses. The pallor within the follicular epithelium represents mucin deposition.

(Ketron-Goodman disease) would now be classified as other, more aggressive forms of cutaneous $\mathrm{T}$ cell lymphoma (e.g. cutaneous aggressive epidermotropic CD8+ lymphoma, cutaneous $\gamma / \delta$ T cell lymphoma or extranodal NK/T cell lymphoma, nasal type) [3].

Histologically, this entity is characterised by marked epidermal hyperplasia and prominent epidermotropism of medium-sized, pleomorphic $\mathrm{T}$ lymphocytes. While a dermal inflammatory infiltrate is also present, this is often less striking than the intraepidermal component and is comprised of a relatively mixed population [34]. Neoplastic cells may also infiltrate eccrine structures [3]. The neoplastic cells typically display a cytotoxic phenotype, but this is not invariable [33, 34]. The prognosis of this subtype of MF is good, although the presence of neoplastic cells within eccrine glands may render superficial treatments less effective. Development of conventional MF has been reported [3].

\section{Unilesional MF}

Besides the pagetoid reticulosis subtype described above, there are also reports of a solitary or unilesional variant of MF having similar histological features to those seen in classical MF [36-39]. Some authors have suggested that these cases have a better prognosis as a group [36], although large cell transformation has been reported [40]. In addition, many of these lesions may in actuality represent other conditions, such as lichenoid keratosis [3, 37, 41], and thus rigorous exclusion of these possibilities (both histologically and clinically) is warranted before rendering a diagnosis of unilesional MF.

\section{Granulomatous MF}

The presence of granulomatous inflammation associated with MF was first reported by Ackerman and Flaxman in 1970 [42]. A granulomatous reaction pattern can be seen at all stages of MF, and while it is most often characterised by 
patchy epithelioid granulomas with variable numbers of giant cells, cases with a more diffuse infiltrate of epithelioid histiocytes also occur [43]. A granulomatous reaction to ruptured follicles may also accompany folliculotropic MF [3]. Granulomatous MF may have a worse prognosis than classic MF. Fewer patients respond to superficial therapies, and there are worse progression-free survival rates. These patients are also at risk for developing a second lymphoma [44, 45].

A particularly rare, but striking, form of MF is known as granulomatous slack skin, characterised by areas of lax, pendulous skin containing a neoplastic $\mathrm{T}$ cell infiltrate. There is epidermotropism as well as a diffuse lymphohistiocytic infiltrate including giant cells throughout the dermis and subcutis $[46,47]$. The initial studies noted prominent elastolysis in association with the granulomatous infiltrate, which was proposed as the mechanism for the lax skin. However, other studies found that elastolysis was not limited to granulomatous slack skin and was more related to the extent of the granulomatous inflammation [45]. In addition, several authors have noted that there is considerable histologic overlap between granulomatous slack skin and granulomatous 'conventional' MF; thus, the diagnosis relies on clinicopathological correlation [3, 43, 45].

\section{Erythrodermic MF}

Erythroderma may develop as a complication of MF and may be associated with lymphadenopathy and circulating neoplastic cells. Erythrodermic MF shares the same histological features as conventional MF [3]. There is overlap with Sézary syndrome, which is defined as a mature $\mathrm{T}$ cell lymphoma characterised by erythroderma, lymphadenopathy and neoplastic T lymphocytes ('Sézary cells') within the blood [1]. However, the term Sézary syndrome is typically reserved for patients presenting with these features from the outset of their disease. This distinction may require careful correlation with the clinical history in order to detect any evidence of preexisting MF [3].

Sézary syndrome is associated with a poor prognosis, having a 5-year survival rate of $24 \%$ [48] and is traditionally regarded as the leukaemic variant of MF. Indeed, no reliable histological criteria for distinguishing the two conditions have been identified [49], although some have suggested that epidermotropism is less often seen in patients with primary Sézary syndrome [50]. However, recent evidence has suggested that the conditions may be derived from different $\mathrm{T}$ cell subsets, with clonal cells from Sézary syndrome patients having an immunophenotype consistent with central memory cells, while those from MF showed a profile more consistent with resident effector memory cells in skin [51]. In addition, recent molecular analyses have identified differences in the molecular profile between these conditions. With array-based comparative genomic hybridisation
(array-CGH) techniques, MF cells were characterised by gains on chromosomes 1 and 7 and losses on chromosome 9. However, cells from patients with Sézary syndrome tended to show gains on chromosomes 8 and 17 and loss on chromosome 10 [52]. These findings suggest that the two conditions may in fact be different diseases and that different treatment regimens may be warranted.

\section{Hypopigmented MF}

Lesions of MF may present with a hypopigmented appearance, particularly in patients with darker skin but also in Caucasians (Fig. 3) [53-55]. This is one of the more frequent variants seen in paediatric patients, and while there is typically a good response to therapy, recurrences are common [56]. Histologically, this subtype is indistinguishable from conventional MF, although a large proportion of these cases show a CD8+ phenotype [57].

\section{Other subtypes}

Numerous other morphological subtypes of MF have been described, based on either clinical or histological features [3]. These include interstitial MF (showing an interstitial infiltrate of lymphocytes dissecting the collagen bundles), poikilodermatous MF (characterised by an atrophic epidermis), hyperpigmented MF, purpuric MF, papular MF, bullous $\mathrm{MF}$, anetodermic MF, pityriasis et varioliformis acuta (PLEVA)-like MF and even an 'invisible' MF, where the skin appears clinically normal [58]. Despite the wide range of subtypes reported, only folliculotropic MF, pagetoid reticulosis and granulomatous slack skin have been considered distinctive enough to be included in the WHO-EORTC classification as separate entities [48].

\section{Parapsoriasis}

The controversial term 'parapsoriasis' was first introduced by Brocq in 1902, to describe a group of dermatoses resembling psoriasis but which lacked some features and showed resistance to therapy [29, 59]. He described three types (parapsoriasis en gouttes, parapsoriasis lichenoides and parapsoriasis en plaques), which he viewed as a group of conditions with features intermediate between cases comprising psoriasis and 'seborrhoea psoriasiformis' and another group comprising lichen planus, pityriasis rubra and MF. Clinically, they were characterised by a long clinical course, absent pruritus, superficiality with possibly some scaling and a resistance to treatment. He described the histological features as a 'round cell' inflammatory infiltrate, dermal and epidermal oedema (i.e. spongiosis), hypogranulosis, hyperkeratosis and parakeratosis [29, 59]. 
Fig. 3 An example of hypopigmented mycosis fungoides. a Clinical appearance, demonstrating multiple hypopigmented macules. b Histological section showing numerous epidermotropic lymphocytes. (Clinical photograph courtesy of Dr Prasad Kumarasinghe)

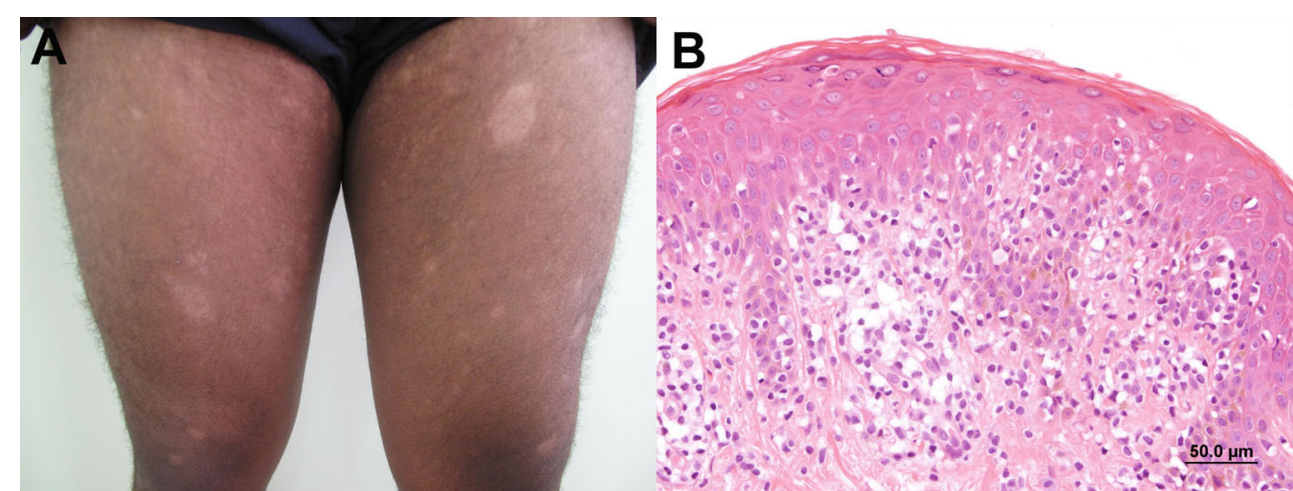

As quoted by Ackerman, Brocq himself acknowledged that 'some cases of mycosis fungoides, for long periods, initially have the aspect of parapsoriasis en plaques' and that the two conditions may be indistinguishable [29, 59]. However, he still regarded them as distinct entities, perhaps due to his perception of a differing prognosis [29], and he argued that the presence of pruritus and dermal infiltration allowed one to separate cases of MF from parapsoriasis.

Over the following decades, the close relationship of parapsoriasis en plaques to MF became apparent. In 1936, Keil noted that parapsoriasis en plaques was complicated by the development of MF 'in so large a percentage of instances as to invite the belief that parapsoriasis in patches and its clinical congeners are probably in most, if not in all cases, the precursors of mycosis fungoides' [29, 60]. In 1953, Degos divided parapsoriasis en plaques into two forms: large plague parapsoriasis and small plaque or digitate parapsoriasis $[29,61]$. He felt that transformation to mycosis fungoides occurred only in large plaque parapsoriasis, with small plaque/digitate parapsoriasis representing a 'benign' form. Subsequently, Sanchez and Ackerman declared that large plaque parapsoriasis was simply an expression of MF and should be renamed as such [9]. Other authors of the time argued against this, preferring to interpret large plaque parapsoriasis as a chronic inflammatory condition, with a risk of developing lymphoma due to ongoing antigen stimulation [62-64]. Subsequent studies have revealed that at least a proportion of cases of parapsoriasis have a dominant $\mathrm{T}$ cell clone present $[65,66]$.

To this day, the term parapsoriasis is associated with confusion. The current concept recognises two entities under this term: small plaque parapsoriasis (also known as chronic superficial dermatitis and digitate dermatosis) and large plaque parapsoriasis. A third condition, pityriasis lichenoides, was initially included in the concept of parapsoriasis but is now recognised as a distinct entity [67]. Indeed, the definition of these conditions is imprecise as there are no recognised size criteria for distinguishing a large plaque from a small plaque and there is no classification for a patient having both small and large lesions. Nonetheless, several texts now consider large plaque parapsoriasis to fall within the spectrum of early MF $[3,67]$ although it is recognised that at this stage, the histological features may be such that a definitive diagnosis is difficult. Small plaque parapsoriasis resembles a mild eczema clinically, and histologically, it shows spongiosis (which may be mild), acanthosis and lymphocytes within the papillary dermis. While a small proportion of these cases have been documented to eventually develop conventional MF [68, 69], the exact relationship between these entities remains a subject of debate.

\section{Immunohistochemistry}

The typical immunophentoype of the neoplastic cells in MF (seen in approximately $75 \%$ of cases) is $\mathrm{CD} 2+, \mathrm{CD} 3+, \mathrm{CD} 4+$, $\mathrm{CD} 5+, \mathrm{CD} 8-, \beta \mathrm{F} 1+, \mathrm{TCR} \gamma-$ and TIA1-. This profile correlates to $\alpha / \beta$ T-helper memory T cells $[1,3,70]$. Some variations have been reported, including examples characterised by the following: CD4-, CD8+ and TIA1+ (cytotoxic profile); CD4- and CD8- (double-negative profile); and $\beta F 1-$, $\mathrm{TCR} \gamma+, \mathrm{CD} 4-, \mathrm{CD} 8+$ and TIA $1+(\gamma / \delta$ profile $)$. However, no clinical or prognostic differences have been demonstrated for these variations to date (noting that previous examples of these immunoprofiles which showed an aggressive course have since been re-classified as other forms of cutaneous $\mathrm{T}$ cell lymphoma, such as CD8+ cytotoxic $\mathrm{T}$ cell lymphoma or cutaneous $\gamma / \delta$ T cell lymphoma) [71-74].

Immunohistochemistry is often utilised in the diagnostic workup of biopsies which are suspected of representing MF. Memory T cells with the same profile as neoplastic MF cells are common in any cutaneous inflammatory infiltrate, limiting the usefulness of this immunoprofile per se. However, loss of one or more pan-T markers (CD2, CD3, CD5 or CD7) can be indicative of a neoplastic process. This loss may be seen throughout the totality of the cutaneous infiltrate or may be limited to the lymphocytes within the epidermis (termed 'discordance' by Michie et al. [75]). While loss of any of these markers can be helpful in the diagnosis of MF, the sensitivity is relatively low, estimated as approximately $10 \%$ for a $\geq 50 \%$ 
loss of $\mathrm{CD} 2, \mathrm{CD} 3$ or $\mathrm{CD} 5$ expression [75]. The sensitivity may be better for loss of CD7, in the order of $40 \%$ for expression levels of less than $10 \%[5,76]$. However, loss of CD7 (as well as other pan-T cell markers) can also be seen rarely in inflammatory conditions $[4,77-80]$, so the finding should be interpreted with some caution.

Immunohistochemical assessment of the $\mathrm{CD} 4 / \mathrm{CD} 8$ ratio has also been touted as a useful diagnostic aide, with the idea being that clonal expansion of a $\mathrm{CD} 4+\mathrm{T}$ cell population would result in an increase in this ratio [78, 81, 82]. Assessment of this ratio can be made difficult by the fact that CD4 also labels intraepidermal Langerhans cells, which may also be increased in the setting of spongiotic disorders [78], and at least one more recent study has not found this ratio to be of discriminatory value $[78,79]$.

Newer immunohistochemical markers may emerge from the results of more advanced molecular studies. As an example, Zhang et al. used microarray-based genomic transcriptome profiling to compare early MF with both inflammatory dermatoses and normal skin [83]. They identified a number of transcripts which were upregulated in MF, including TOX (a regulator of early T cell development) and PDCD1 (a pro-apoptosis regulator). The authors were able to demonstrate that immunohistochemistry for TOX labelled T cells strongly in cases of MF, including cells within Pautrier microabscesses [83].

\section{Molecular techniques}

The functional diversity required for an effective adaptive immune system is generated by complex rearrangements within antigen receptor genes. This involves alterations of the tertiary gene structure, with recombination of variable, diversity and joining regions within the gene, as well as insertion and deletion of random nucleotides via the action of terminal deoxynucleotidyl transferase (TdT) [84]. Modern molecular techniques attempt to exploit the uniqueness of each rearranged receptor gene to determine whether a population of lymphocytes is clonal or polyclonal. Clonally identical lymphocytes share identical receptor gene rearrangements and yield amplicons of the same size after amplification by PCR, whereas polyclonal lymphocytes yield amplicons having a range of sizes. Monoclonal rearrangements will appear as a discrete band or peak, whilst polyclonal rearrangements appear as a smear or Gaussian curve, depending on the modality used to anlayse the DNA fragments [84].

Clonal T cell receptor (TCR) gene rearrangements can be detected in a large proportion of MF cases, with a sensitivity ranging from $50 \%$ to greater than $70 \%$, depending on the methodology and the stage of the lesions [85-94]. PCR analysis has been shown to be more sensitive than the Southern blot method used in the older literature [90]. Typically, a PCR analysis would involve the use of a range of primers directed against conserved regions within the receptor genes. The first generation of these tests suffered from a lack of consistency across different groups and platforms, making it difficult to determine the optimum diagnostic approach [84]. In 2003, the BIOMED-2 collaborative study outlined a set of standard PCR primers and methodology, which forms the basis of modern PCR clonality testing $[95,96]$. We use this primer set and methodology routinely.

The initial analyses of the BIOMED-2 protocol indicated a sensitivity of approximately $99 \%$ for the detection of clonality in T cell neoplasms [97]. However, this analysis utilised fresh or frozen tissue and did not include primary CTCLs. Goeldel et al. found a sensitivity of $77 \%$ for the diagnosis of CTCL using the BIOMED-2 protocol, with a specificity of $86 \%$ [91]. However, they also used exclusively frozen tissue. Using archived formalin-fixed, paraffin-embedded (FFPE) tissue, Lukowsky et al. were able to demonstrate a sensitivity of $81 \%$ [92], while in a smaller sample of granulomatous CTCL, Pfaltz et al. found a sensitivity of $94 \%$ [93].

PCR analysis is often employed as an adjunct in the diagnosis of early-stage lesions. Perhaps not surprisingly, early patch stage lesions typically show the lowest sensitivities, presumably due to the relative paucity of neoplastic cells within the infiltrate $[85,86,98]$. Cerroni et al. showed that the neoplastic cells are often present within the epidermis in these early lesions and suggested that sensitivities might be increased by microdissection of the epidermis [87]. The presence of monoclonality does not appear to be associated with any prognostic significance [72].

Despite deficits in sensitivity, Alessi et al. were still able to use the technique to reclassify a number of cases as MF when a monoclonal result was combined with the clinical and histological features of the cases [85], demonstrating that the technique is a useful additional test when the results are correlated with the other diagnostic modalities. However, it should be noted that monoclonal TCR gene arrangements have been documented in a range of benign inflammatory dermatoses, including lichen planus, pityriasis lichenoides, lichen sclerosus, granuloma annulare and chronic eczema [93, 98-102]. In addition, other factors can potentially confound the interpretation of the result, including clonal heterogeneity within a lesion, poorly annealing primers or false positives due to limited numbers of lymphocytes within a sample [84].

The specificity of using PCR to detect monoclonal TCR gene rearrangements may be improved by testing two different skin sites, with the requirement that identical clones need to be identified to represent a positive result. Thurner et al. demonstrated a sensitivity of $80 \%$ utilising this method, and they were able to demonstrate identical clones in $85 \%$ of a group of patients who had an indeterminate result on initial histological examination but subsequently went on to develop 
MF [103]. In addition, the ability to perform analyses on multiple biopsies may allow for the correct identification of a stable pathological clone in the setting of clonal heterogeneity, which has been documented in $30-48 \%$ of MF cases $[104,105]$.

\section{Differential diagnosis}

The histological diagnosis of early MF can be extremely challenging, due to the protean nature of the disease and its ability to mimic many inflammatory dermatoses, both clinically and histologically [106, 107]. This has led some authors to label it as 'the great imitator' of modern dermatopathology, a designation once applied to syphilis [107]. The difficulties are reflected in interobserver variability studies, which have shown only fair to moderate agreement between pathologists with regard to early MF diagnosis [78].

Despite the broad range of potential differentials, there are a number of conditions which seem to be more commonly considered in routine practice.

\section{a. Spongiotic dermatoses}

Spongiotic dermatoses are often under consideration (Fig. 4a, b), especially as the lesions are often suspected to be eczematous clinically (indeed, in our experience, there is often a history of 'eczema' which is refractory to treatment). A degree of spongiosis is often seen in early MF, and marked spongiosis has been documented in a small percentage of cases [7]. The presence of numbers of intraepithelial lymphocytes which are disproportionate to the amount of spongiosis is often quoted as a distinguishing feature [7, 8]; however, clearly, this assessment is subjective. In their original study, Sanchez and Ackerman suggested that spongiotic microvesiculation argued against MF [9]. While immunohistochemical and molecular analyses may help in selected cases, ultimately, the distinction rests on careful clinicopathological correlation [108].

b. Psoriasiform or interface dermatitis

Changes of psoriasiform or interface dermatitis are also well recognised in lesions of MF [13, 109]. Indeed, a psoriasiform lichenoid or a spongiotic psoriasiform lichenoid pattern is typical of the low power appearance of MF [110]. Massone et al. reported changes of interface dermatitis in up to $59 \%$ of cases of their cases of early MF [7]. While this was typically a focal finding, in a small number of cases, the changes involved much of the dermoepidermal junction, and necrotic keratinocytes were also occasionally present. Lichen sclerosus is one example of an interface dermatosis which is recognised as a potential mimic of MF (Fig.4c, d) [108]. With regard to the latter, it is useful to recall that the first biopsy of MF will almost never come from genital skin, which is seldom involved in early MF. Of course, extragenital lichen sclerosus can present a more troubling mimic. In addition, a recently described entity known as annular lichenoid dermatitis of youth (ALDY) may also be a cause of confusion [111]. These patients, as the name suggests, are typically young and present with erythematous macules and annular lesions on the groin and flanks. The clinical appearances are reminiscent of MF, and histologically, the cases are characterised by a band-like inflammatory reaction pattern with lichenoid interface changes. While these histological features can be confused with MF, in ALDY, the lymphocytes are seen predominantly at the tips of rete ridges, where they are often associated with prominent keratinocyte apoptosis [111].

c. Pigmented purpuric dermatoses

Massone et al. [7] also documented the presence of melanophages and extravasated erythrocytes in a small percentage of cases, imparting a resemblance to the group of dermatoses known collectively as pigmented purpuric dermatoses (PPDs). Purpuric lesions occur in MF [112], the histological features of PPDs and MF show significant overlap [110, 113], and clonal rearrangements of $\mathrm{T}$ cell receptor genes have been documented in a relatively high proportion of PPD cases [110]. Indeed, there is ongoing debate as to whether a subset of PPD represents a precursor to MF, or simply a mimic [110]. From a practical point of view, restriction of lesions to the lower legs is indicative of a PPD.

d. Pseudolymphomatoid drug reactions

Drug reactions have also been documented to cause a histological reaction similar to MF. These 'pseudolymphomatoid' drug reactions have been associated with a wide range of drugs, including phenytoin [114], carbamazepine [115], captopril, enalapril [116], fluoxetine, amitriptyline [117], antihistamines [118] and imatinib [119], amongst others [120]. Magro et al. have proposed that histological features favouring a pseudolymphomatoid drug reaction include vacuolar degeneration of basal keratinocytes, necrotic keratinocytes, moderate to marked spongiosis and papillary dermal oedema [120]. Again, a thorough clinical history, including details of any medications, is likely to be the most useful criterion.

e. MF subtype mimics

In addition to the conditions listed above, which can be confused with classical MF, the various subtypes have unique differentials of their own, relating to their particular histological characteristics. Folliculotropic MF can be confused with perifolliculitis, an epidermoid cyst in the comedonal forms, or a basal cell carcinoma in the basaloid folliculolymphoid hyperplasia form [18]. Syringotropic MF needs to be distinguished from perniosis or autoimmune forms of hidradenitis [28]. Granulomatous MF can be mistaken for a granulomatous dermatitis [43], and 


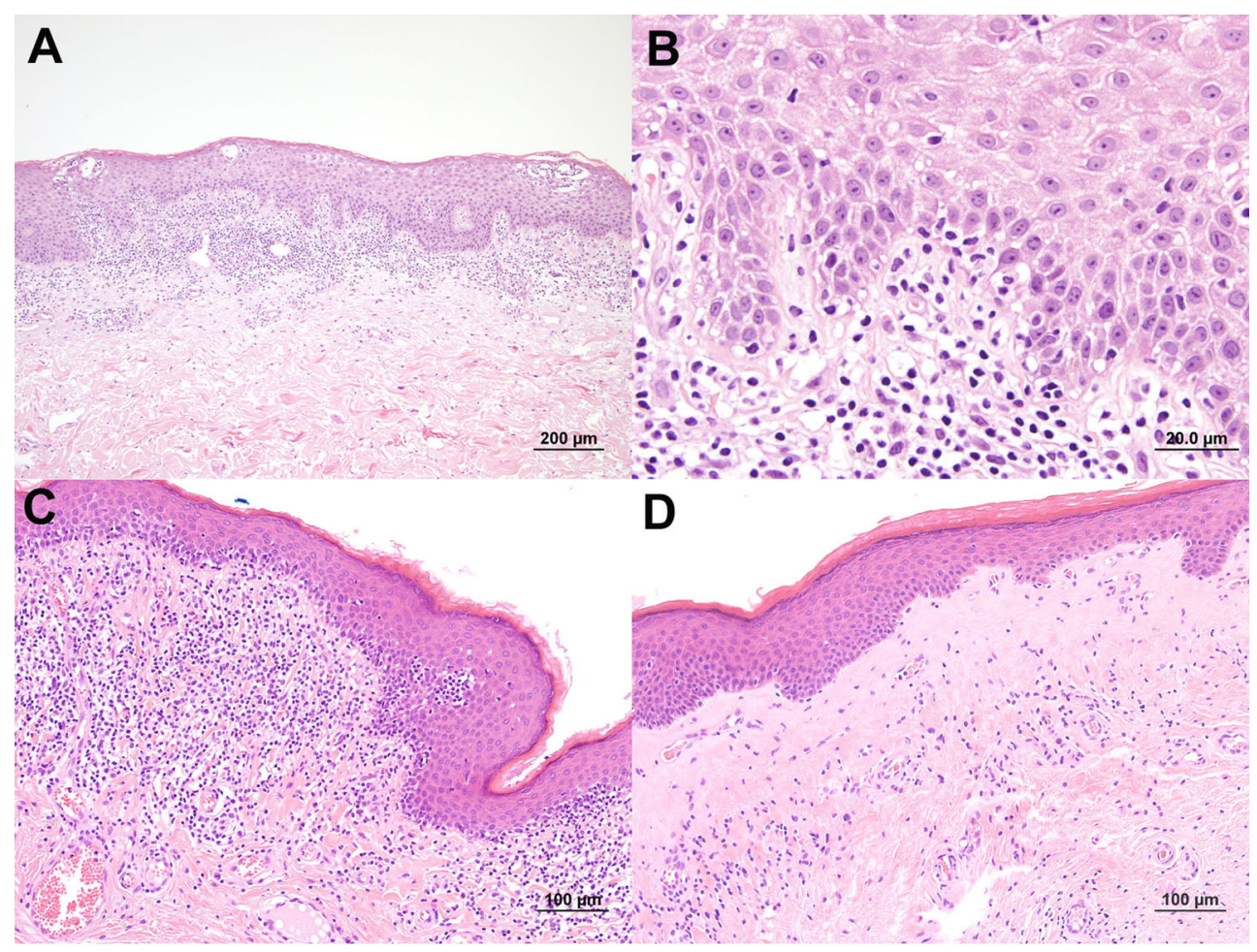

Fig. 4 Two examples of cases showing morphological overlap with inflammatory conditions. a A low power view of this specimen from the flank shows spongiosis with a band-like lymphocytic infiltrate within the dermis. There are small vesicles within the epidermis, some of which contain lymphocytes. b At higher power, occasional linear arrays of lymphocytes are seen within the basal epidermis, some of which show irregular nuclear contours and a surrounding halo. The background spongiosis is readily apparent in this panel. This patient had an established history of classical mycosis fungoides, with

hypopigmented MF enters the differential diagnosis of vitiligo [121].

f. Other cutaneous $\mathrm{T}$ cell lymphoproliferative disorders

Finally, cases of possible MF need to be distinguished from other forms of cutaneous lymphoma. Epidermotropism may be a feature of extranodal NK/T cell lymphoma (nasal type), primary cutaneous aggressive epidermotropic CD8+ cytotoxic T cell lymphoma and cutaneous $\gamma / \delta \mathrm{T}$ cell lymphoma [48], as well as some subtypes of lymphomatoid papulosis (in particular types B and D) $[48,122]$. While immunoprofiling of the neoplastic cells may help in the distinction between these entities, the range of immunophenotypes documented for MF may overlap with these other cutaneous lymphoproliferative disorders (see above). Indeed, many cases were likely to have been previously classified as variants of MF. The clinical behaviour of extranodal NK/T cell lymphoma (nasal type), primary cutaneous aggressive epidermotropic CD8+ cytotoxic T cell lymphoma and cutaneous $\gamma / \delta \mathrm{T}$ cell lymphoma is much more aggressive than that of MF, and thus, it is critical to identify these conditions in particular. Once demonstration of identical clonal $\mathrm{T}$ cell populations in multiple biopsies, including this sample. This biopsy was interpreted as mycosis fungoides, rather than as spongiotic dermatitis. $\mathbf{c}$ This medium power view of a specimen of foreskin demonstrates features which could easily be mistaken for mycosis fungoides. There is a band-like infiltrate of lymphocytes with apparent epidermotropism of lymphocytes, including a focal intra-epidermal collection which could be interpreted as a Pautrier's microabscess. d However, elsewhere, the features are more typical of lichen sclerosis, which was the diagnosis rendered in this case

again, correlation with the clinical features is most likely to yield a correct diagnosis.

\section{Our algorithmic approach to the diagnosis of early MF}

There is no foolproof approach to biopsies where early- or patch-stage MF is a consideration. Nonetheless, we have attempted in the following paragraphs to summarise our general approach to this situation (Fig. 5).

As with all biopsies, the initial step involves assessing the overall histological pattern of the process. As described above, MF is typically characterised by a band-like infiltrate of lymphocytes within the dermis, with 'psoriasiform lichenoid', 'psoriasiform spongiotic lichenoid' and 'atrophic lichenoid' patterns regarded as typical of MF [110]. Assessing the histological pattern also brings to mind potential differential diagnoses, and specific features of those conditions should be sought: Positive recognition of an alternative dermatosis is 
Fig. 5 A flow chart summarising our approach to a biopsy where mycosis fungoides is a diagnostic possibility. Please refer to the text for details

\section{Step 1: Identify the pattern.}

Band-like lymphocytic infiltrate Psoriasiform lichenoid

Psoriasiform spongiotic lichenoid Atrophic lichenoid

BUT, don't forget the subtypes and their patterns

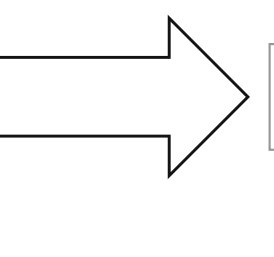

Are there specific features of another inflammatory condition?

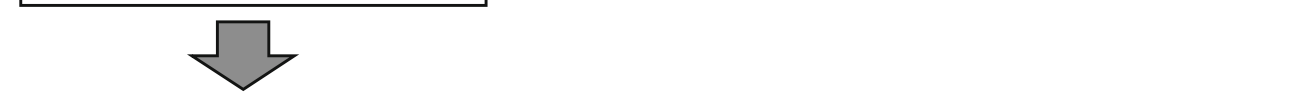

\section{Step 2: Is there epidermotropism?}

Linear arrays of lymphocytes along the basal layer

Pautrier's microabscesses

Folliculotropism or syringotropism if

relevant

Are the lymphocytes proportional to any

spongiosis?
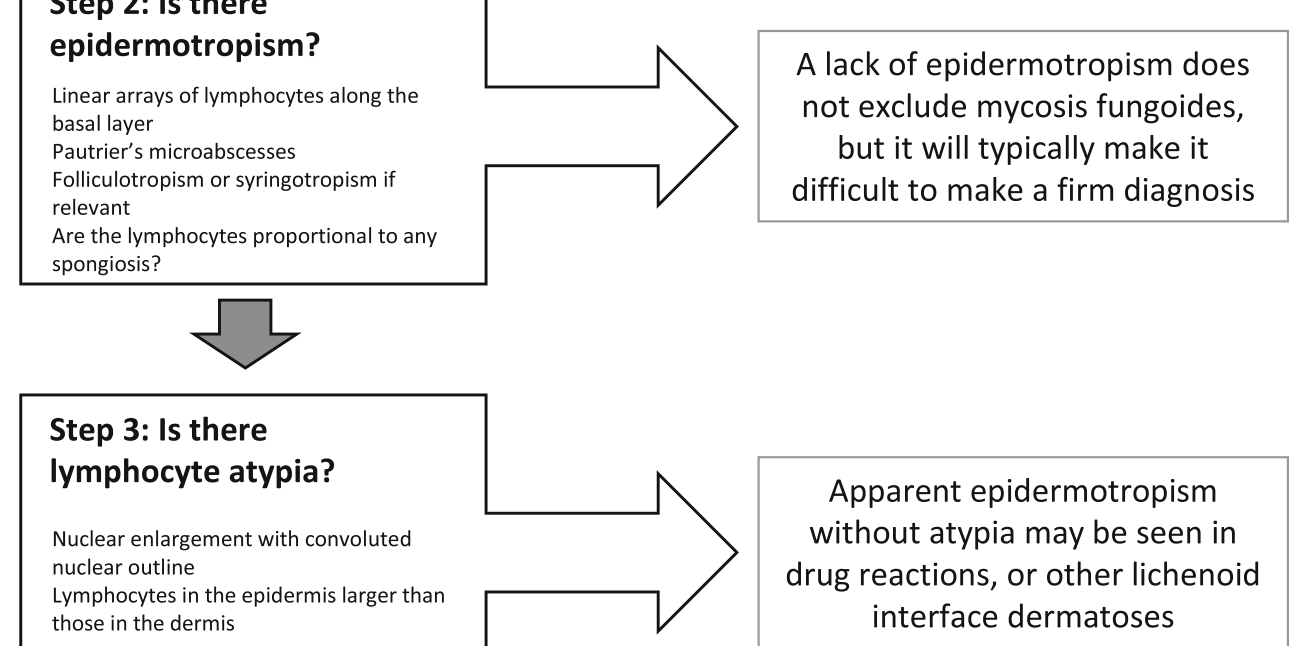

of great value when attempting to 'exclude MF'! Pathologists should also be cognizant of the various subtypes of MF listed above, and of the variant histological patterns, they may present.
Once we have established that the histological pattern may be compatible with MF or one of its variants, we next assess whether epidermotropism is present. While the absence of 
epidermotropism does not exclude a diagnosis of MF, it does limit the ability to make a definite histological diagnosis.

Once the presence of epidermotropism is established, we next turn our attention to the presence or absence of the various diagnostic features that are described above. In particular, we look for the presence of clusters of intraepidermal lymphocytes (do they represent Pautrier microabscesses?), haloing of lymphocytes, basilar epidermotropism and fibrosis of the papillary dermis. If there is accompanying spongiosis, we attempt to make a judgement as to whether the number of lymphocytes within the epidermis is disproportionate to the spongiosis. We also pay attention to the cytological details of the epidermotropic lymphocytes, in particular noting whether they have convoluted nuclear membranes and whether they are larger than dermal lymphocytes. In our experience, thin sections (e.g. $2 \mu \mathrm{m}$ thick) are useful for this assessment, and we routinely request thin sections in cases of possible MF.

At this point in our assessment, we have formed an opinion as to whether MF is a reasonable consideration and how strongly the histological features support this. We then interpret these features in light of the clinical scenario. This will almost always involve direct communication with the referring clinician, either via phone or a clinicopathological conference. If both the clinical and histological features support the diagnosis, we will usually make a diagnosis of MF without any further studies. If the clinical features are not compatible, we would review the case, mindful of potential differential diagnoses. A drug history can be particularly useful in this scenario. If the clinical features are strongly suggestive of MF, it can be virtually impossible to exclude it histologically unless a definitive diagnosis of another condition can be rendered [3].

If there is still uncertainty after careful consideration of the clinical and histological features, we then consider ancillary testing. This would typically involve immunohistochemistry as well as molecular studies for clonal TCR gene rearrangements, particularly testing of lesions from multiple sites and/or at different points in time.

It is important to recognise that patch stage MF is a clinically indolent condition with a protracted course. Currently available treatments do not alter the prognosis. There is significant overlap of treatment modalities between early MF and the inflammatory conditions which enter the differential diagnosis, with the caveat that biologic immunomodulatory agents have been associated with progression of MF in some case reports and should be avoided if MF remains a consideration. In this context, it is appropriate that cases which fall short of a definitive diagnosis be reported descriptively, highlighting the differential diagnostic considerations. In these cases, symptomatic management and clinical follow-up in a multidisciplinary team setting is undertaken. An iterative approach to clinical evaluation and biopsy can resolve many cases satisfactorily. It is preferable to avoid overdiagnosis of MF in such circumstances - it is easy to 'upgrade' a temporising diagnosis such as 'superficial cutaneous T cell infiltrate of uncertain character, please refer to the comment', while a premature diagnosis of MF may be almost impossible to revise.

\section{Conclusion}

MF is the most common cutaneous T cell lymphoma, and any pathologist who deals with skin specimens, particularly dermatopathologists or haematopathologists, needs an approach towards a biopsy where early MF is considered. As well as being aware of the key histological criteria for 'classical' MF, pathologists need to be mindful of the many and varied subtypes which can present histological findings showing considerable overlap with other dermatological conditions. A familiarity with the clinical and histological features of these inflammatory considerations is a sine qua non for approaching such a biopsy. Similarly, it is important to actively consider those neoplastic conditions which may mimic MF histologically, particularly lymphomatoid papulosis and the more aggressive forms of cutaneous $\mathrm{T}$ cell lymphoma.

While immunohistochemistry and molecular techniques may help, they should not supersede careful and considered correlation with the clinical features, which remains by far the most useful 'adjunct test'. In difficult cases, it is appropriate to reserve definitive diagnosis and follow the patient in a multidisciplinary setting; 'tincture of time' is the second most useful 'adjunct test' in such circumstances. Early MF can be a hard, at times almost impossible, diagnosis. But, delay in diagnosis does not often lead to significant morbidity. The cost of premature overdiagnosis is likely to be much greater.

\section{Compliance with ethical standards}

Funding No separate funding was received for the preparation of this article.

Conflict of interest The authors declare that they have no conflicts of interest.

Ethical approval This is a review article and does not contain any studies with human participants performed by any of the authors.

\section{References}

1. Jaffe ES, Harris NL, Stein H, Vardiman JW (eds) (2001) WHO classification of tumours - pathology and genetics of tumours of haematopoietic and lymphoid tissues. IARC Press, Lyon

2. Alibert JLM (ed) (1806) Tableau du pian fungoide. Description des Maladies de la peau observees a l'Hospital Saint Louis. Barrois L'aine et Fils, Paris

3. Cerroni L (2014) Skin lymphoma: the illustrated guide, 4th edn. John Wiley \& Sons, West Sussex 
4. Willemze R (2012) Cutaneous T-cell lymphoma. In: Bolognia JL, Jorizzo JL, Schaffer JV (eds) Dermatology, vol 2, 3rd edn. Elsevier, New Haven

5. Pimpinelli N, Olsen EA, Santucci M, Vonderheid E, Haeffner AC, Stevens S, Burg G, Cerroni L, Dreno B, Glusac E, Guitart J, Heald PW, Kempf W, Knobler R, Lessin S, Sander C, Smoller BS, Telang G, Whittaker S, Iwatsuki K, Obitz E, Takigawa M, Turner ML, Wood GS, International Society for Cutaneous L (2005) Defining early mycosis fungoides. J Am Acad Dermatol 53(6):1053-1063. doi:10.1016/j.jaad.2005.08.057

6. Guitart J, Kennedy J, Ronan S, Chmiel JS, Hsiegh YC, Variakojis D (2001) Histologic criteria for the diagnosis of mycosis fungoides: proposal for a grading system to standardize pathology reporting. J Cutan Pathol 28(4):174-183

7. Massone C, Kodama K, Kerl H, Cerroni L (2005) Histopathologic features of early (patch) lesions of mycosis fungoides: a morphologic study on 745 biopsy specimens from 427 patients. Am J Surg Pathol 29(4):550-560

8. Nickoloff BJ (1988) Light-microscopic assessment of 100 patients with patch/plaque-stage mycosis fungoides. Am J Dermatopathol 10(6):469-477

9. Sanchez JL, Ackerman AB (1979) The patch stage of mycosis fungoides. Criteria for histologic diagnosis. Am J Dermatopathol 1(1):5-26

10. Santucci M, Biggeri A, Feller AC, Massi D, Burg G (2000) Efficacy of Histologic criteria for diagnosing early mycosis fungoides: an EORTC cutaneous lymphoma study group investigation. European organization for research and treatment of cancer. Am J Surg Pathol 24(1):40-50

11. Shapiro PE, Pinto FJ (1994) The Histologic spectrum of mycosis fungoides/sezary syndrome (cutaneous T-cell lymphoma). a review of 222 biopsies, including newly described patterns and the earliest pathologic changes. Am J Surg Pathol 18(7):645-667

12. King-Ismael D, Ackerman AB (1992) Guttate parapsoriasis/digitate dermatosis (small plaque parapsoriasis) is mycosis fungoides. Am J Dermatopathol 14(6):518-530, discussion 531-515

13. Naraghi ZS, Seirafi H, Valikhani M, Farnaghi F, Kavusi S, Dowlati Y (2003) Assessment of Histologic criteria in the diagnosis of mycosis fungoides. Int J Dermatol 42(1):45-52

14. Smoller BR, Bishop K, Glusac E, Kim YH, Hendrickson M (1995) Reassessment of histologic parameters in the diagnosis of mycosis fungoides. Am J Surg Pathol 19(12):1423-1430

15. Kim SY (1985) Follicular mycosis fungoides. Am J Dermatopathol 7(3):300-301

16. Lacour JP, Castanet J, Perrin C, Ortonne JP (1993) Follicular mycosis fungoides. A clinical and Histologic variant of cutaneous T-cell lymphoma: report of two cases. J Am Acad Dermatol 29(2 Pt 2):330-334

17. van Doorn R, Scheffer E, Willemze R (2002) Follicular mycosis fungoides, a distinct disease entity with or without associated follicular mucinosis: a clinicopathologic and follow-up study of 51 patients. Arch Dermatol 138(2):191-198

18. Gerami P, Guitart J (2007) The spectrum of histopathologic and immunohistochemical findings in folliculotropic mycosis fungoides. Am J Surg Pathol 31(9):1430-1438. doi:10.1097/ PAS.0b013e3180439bdc

19. Cerroni L (2010) Pilotropic mycosis fungoides: a clinicopathologic variant of mycosis fungoides yet to be completely understood. Arch Dermatol 146(6):662-664. doi:10.1001/archdermatol.2010.93

20. Lehman JS, Cook-Norris RH, Weed BR, Weenig RH, Gibson LE, Weaver AL, Pittelkow MR (2010) Folliculotropic mycosis fungoides: single-center study and systematic review. Arch Dermatol 146(6):607-613. doi:10.1001/archdermatol.2010.101

21. Muniesa C, Estrach T, Pujol RM, Gallardo F, Garcia-Muret P, Climent J, Servitje O (2010) Folliculotropic mycosis fungoides: clinicopathological features and outcome in a series of 20 cases. J Am Acad Dermatol 62(3):418-426. doi:10.1016/j.jaad.2009.03.014

22. van Doorn R, Van Haselen CW, van Voorst Vader PC, Geerts ML, Heule F, de Rie M, Steijlen PM, Dekker SK, van Vloten WA, Willemze R (2000) Mycosis fungoides: disease evolution and prognosis of 309 Dutch patients. Arch Dermatol 136(4):504-510

23. Gerami P, Rosen S, Kuzel T, Boone SL, Guitart J (2008) Folliculotropic mycosis fungoides: an aggressive variant of cutaneous T-cell lymphoma. Arch Dermatol 144(6):738-746. doi:10. 1001/archderm.144.6.738

24. Pinkus H (1957) Alopecia mucinosa; inflammatory plaques with alopecia characterized by root-sheath mucinosis. AMA Arch Dermatol 76(4):419-424, discussion 424-416

25. Cerroni L, Fink-Puches R, Back B, Kerl H (2002) Follicular mucinosis: a critical reappraisal of clinicopathologic features and association with mycosis fungoides and Sezary syndrome. Arch Dermatol 138(2):182-189

26. Hempstead RW, Ackerman AB (1985) Follicular mucinosis. A reaction pattern in follicular epithelium. The American Journal of dermatopathology 7(3):245-257

27. Boer A, Guo Y, Ackerman AB (2004) Alopecia mucinosa is mycosis fungoides. The American Journal of dermatopathology 26(1):33-52

28. Pileri A, Facchetti F, Rutten A, Zumiani G, Boi S, Fink-Puches R, Cerroni L (2011) Syringotropic mycosis fungoides: a rare variant of the disease with peculiar clinicopathologic features. Am J Surg Pathol 35(1):100-109. doi:10.1097/PAS.0b013e3182036ce7

29. Ackerman AB, Denianke K, Sceppa J, Asgari M, Milette F, Sanchez JA (2008) Mycosis fungoides: perspective historical allied with critique methodical for the purpose of illumination maximal. Ardor Scribendi, New York

30. Woringer F, Kolopp P (1939) Lesion erythematosqumeuse polycyclique de l'avant-bras evoluant depuis 6 ans chez ungarconnet de 13 ans. Ann Dermatol Syphiligr 10:945-958

31. Braun-Falco O, Marghescu S, Wolff HH (1973) Pagetoide reticulosis-woringer-Kolopp's disease. Hautarzt Z fur Dermatol Venerologia und verwandte Gebiete 24(1):11-21

32. Ioannides G, Engel MF, Rywlin AM (1983) Woringer-kolopp disease (pagetoid reticulosis). Am J Dermatopathol 5(2):153-158

33. Burns MK, Chan LS, Cooper KD (1995) Woringer-kolopp disease (localized pagetoid reticulosis) or unilesional mycosis fungoides? an analysis of eight cases with benign disease. Arch Dermatol 131(3):325-329

34. Haghighi B, Smoller BR, LeBoit PE, Warnke RA, Sander CA, Kohler S (2000) Pagetoid reticulosis (woringer-kolopp disease): an immunophenotypic, molecular, and clinicopathologic study. Mod Pathol Off J United States and Canadian Acad Pathol Inc 13(5):502-510. doi:10.1038/modpathol.3880088

35. Waitzer S, Fisher BK (1984) Woringer-kolopp disease. A form of mycosis fungoides. Int J Dermatol 23(9):610-612

36. Ally MS, Pawade J, Tanaka M, Morris S, Mitchell T, Child F, Wain M, Whittaker S, Robson A (2012) Solitary mycosis fungoides: a distinct clinicopathologic entity with a good prognosis: a series of 15 cases and literature review. J Am Acad Dermatol 67(4):736-744. doi:10.1016/j.jaad.2012.02.039

37. Cerroni L, Fink-Puches R, El-Shabrawi-Caelen L, Soyer HP, LeBoit PE, Kerl H (1999) Solitary skin lesions with histopathologic features of early mycosis fungoides. Am J Dermatopathol 21(6):518-524

38. Heald PW, Glusac EJ (2000) Unilesional cutaneous T-cell lymphoma: clinical features, therapy, and follow-up of 10 patients with a treatment-responsive mycosis fungoides variant. J Am Acad Dermatol 42(2 Pt 1):283-285. doi:10.1016/S01909622(00)90140-3

39. Oliver GF, Winkelmann RK (1989) Unilesional mycosis fungoides: a distinct entity. J Am Acad Dermatol 20(1):63-70 
40. Ohtani T, Kikuchi K, Koizumi H, Kunii T, Aiba S (2009) A case of CD30+ large-cell transformation in a patient with unilesional patch-stage mycosis fungoides. Int J Dermatol 48(6):623-626. doi:10.1111/j.1365-4632.2009.03976.x

41. Kossard S (1997) Unilesional mycosis fungoides or lymphomatoid keratosis? Arch Dermatol 133(10):1312-1313

42. Ackerman AB, Flaxman BA (1970) Granulomatous mycosis fungoides. Br J Dermatol 82(4):397-401

43. Scarabello A, Leinweber B, Ardigo M, Rutten A, Feller AC, Kerl H, Cerroni L (2002) Cutaneous lymphomas with prominent granulomatous reaction: a potential pitfall in the histopathologic diagnosis of cutaneous T- and B-cell lymphomas. Am J Surg Pathol 26(10):1259-1268

44. Li JY, Pulitzer MP, Myskowski PL, Dusza SW, Horwitz S, Moskowitz A, Querfeld C (2013) A case-control study of clinicopathologic features, prognosis, and therapeutic responses in patients with granulomatous mycosis fungoides. J Am Acad Dermatol 69(3):366-374. doi:10.1016/j.jaad.2013.03.036

45. Kempf W, Ostheeren-Michaelis S, Paulli M, Lucioni M, Wechsler J, Audring H, Assaf C, Rudiger T, Willemze R, Meijer CJ, Berti E, Cerroni L, Santucci M, Hallermann C, Berneburg M, Chimenti S, Robson A, Marschalko M, Kazakov DV, Petrella T, Fraitag S, Carlotti A, Courville P, Laeng H, Knobler R, Golling P, Dummer R, Burg G, Cutaneous Lymphoma Histopathology Task Force Group of the European Organization for R, Treatment of C (2008) Granulomatous mycosis fungoides and granulomatous slack skin: a multicenter study of the cutaneous lymphoma histopathology task force group of the european organization for research and treatment of cancer (EORTC). Arch Dermatol 144(12):1609-1617. doi:10. 1001/archdermatol.2008.46

46. LeBoit PE, Beckstead JH, Bond B, Epstein WL, Frieden IJ, Parslow TG (1987) Granulomatous slack skin: clonal rearrangement of the T-cell receptor beta gene is evidence for the lymphoproliferative nature of a cutaneous elastolytic disorder. J Invest Dermatol 89(2):183-186

47. LeBoit PE, Zackheim HS, White CR Jr (1988) Granulomatous variants of cutaneous T-cell lymphoma. The histopathology of granulomatous mycosis fungoides and granulomatous slack skin. Am J Surg Pathol 12(2):83-95

48. Willemze R, Jaffe ES, Burg G, Cerroni L, Berti E, Swerdlow SH, Ralfkiaer E, Chimenti S, Diaz-Perez JL, Duncan LM, Grange F, Harris NL, Kempf W, Kerl H, Kurrer M, Knobler R, Pimpinelli N, Sander C, Santucci M, Sterry W, Vermeer MH, Wechsler J, Whittaker S, Meijer CJ (2005) WHO-EORTC classification for cutaneous lymphomas. Blood 105(10):3768-3785. doi:10.1182/ blood-2004-09-3502

49. Kamarashev J, Burg G, Kempf W, Hess Schmid M, Dummer R (1998) Comparative analysis of histological and immunohistological features in mycosis fungoides and sezary syndrome. J Cutan Pathol 25(8):407-412

50. Diwan AH, Prieto VG, Herling M, Duvic M, Jone D (2005) Primary sezary syndrome commonly shows low-grade cytologic atypia and an absence of epidermotropism. Am J Clin Pathol 123(4):510-515. doi:10.1309/YB79-JG4T-MJER-Q7PV

51. Campbell JJ, Clark RA, Watanabe R, Kupper TS (2010) Sezary syndrome and mycosis fungoides arise from distinct $\mathrm{T}-$ cell subsets: a biologic rationale for their distinct clinical behaviors. Blood 116(5):767-771. doi:10.1182/blood-2009-11-251926

52. van Doorn R, van Kester MS, Dijkman R, Vermeer MH, Mulder AA, Szuhai K, Knijnenburg J, Boer JM, Willemze R, Tensen CP (2009) Oncogenomic analysis of mycosis fungoides reveals major differences with Sezary syndrome. Blood 113(1):127-136. doi:10. 1182/blood-2008-04-153031

53. Akaraphanth R, Douglass MC, Lim HW (2000) Hypopigmented mycosis fungoides: treatment and a 6(1/2)-year follow-up of 9 patients. J Am Acad Dermatol 42(1 Pt 1):33-39
54. Breathnach SM, McKee PH, Smith NP (1982) Hypopigmented mycosis fungoides: report of five cases with Ultrastructural observations. Br J Dermatol 106(6):643-649

55. Stone ML, Styles AR, Cockerell CJ, Pandya AG (2001) Hypopigmented mycosis fungoides: a report of 7 cases and review of the literature. Cutis 67(2):133-138

56. Castano E, Glick S, Wolgast L, Naeem R, Sunkara J, Elston D, Jacobson M (2013) Hypopigmented mycosis fungoides in childhood and adolescence: a long-term retrospective study. J Cutan Pathol 40(11):924-934. doi:10.1111/cup.12217

57. El-Shabrawi-Caelen L, Cerroni L, Medeiros LJ, McCalmont TH (2002) Hypopigmented mycosis fungoides: frequent expression of a CD8+ T-cell phenotype. Am J Surg Pathol 26(4):450-457

58. Pujol RM, Gallardo F, Llistosella E, Blanco A, Bernado L, Bordes R, Nomdedeu JF, Servitje O (2000) Invisible mycosis fungoides: a diagnostic challenge. J Am Acad Dermatol 42(2 Pt 2):324-328

59. Brocq L (1902) Les parapsoriasis. Ann Dermatol Syphiligr 33: 433-468

60. Keil H (1936) Parapsoriasis en plaques disseminees and incipient mycosis fungoides. Arch Dermatol Syphilol 37:466-494

61. Degos R (1953) Dermatoses erythmato-squameuses. In: Dermatologie. Flamarion, Paris

62. Lambert WC, Everett MA (1981) The nosology of parapsoriasis. J Am Acad Dermatol 5(4):373-395

63. Fransway AF, Winkelmann RK (1988) Chronic dermatitis evolving to mycosis fungoides: report of four cases and review of the literature. Cutis 41(5):330-335

64. Lambert WC (1985) Premycotic eruptions. Dermatol Clin 3(4): 629-645

65. Haeffner AC, Smoller BR, Zepter K, Wood GS (1995) Differentiation and clonality of lesional lymphocytes in small plaque parapsoriasis. Arch Dermatol 131(3):321-324

66. Simon M, Flaig MJ, Kind P, Sander CA, Kaudewitz P (2000) Large plaque parapsoriasis: clinical and genotypic correlations. J Cutan Pathol 27(2):57-60

67. Weedon D (2010) Weedon's skin pathology. Elsevier, London

68. Belousova IE, Vanecek T, Samtsov AV, Michal M, Kazakov DV (2008) A patient with clinicopathologic features of small plaque parapsoriasis presenting later with plaque-stage mycosis fungoides: report of a case and comparative retrospective study of 27 cases of "nonprogressive" small plaque parapsoriasis. J Am Acad Dermatol 59(3):474 482. doi:10.1016/j.jaad.2008.05.028

69. Vakeva L, Sarna S, Vaalasti A, Pukkala E, Kariniemi AL, Ranki A (2005) A retrospective study of the probability of the evolution of parapsoriasis en plaques into mycosis fungoides. Acta Derm Venereol 85(4):318-323. doi:10.1080/00015550510030087

70. Ralfkiaer E, Wantzin GL, Mason DY, Hou-Jensen K, Stein H, Thomsen K (1985) Phenotypic characterization of lymphocyte subsets in mycosis fungoides. Comparison with large plaque parapsoriasis and benign chronic dermatoses. Am J Clin Pathol 84(5):610-619

71. Hodak E, David M, Maron L, Aviram A, Kaganovsky E, Feinmesser M (2006) CD4/CD8 double-negative epidermotropic cutaneous T-cell lymphoma: an immunohistochemical variant of mycosis fungoides. J Am Acad Dermatol 55(2):276-284. doi:10. 1016/j.jaad.2006.01.020

72. Massone C, Crisman G, Kerl H, Cerroni L (2008) The prognosis of early mycosis fungoides is not influenced by phenotype and Tcell clonality. Br J Dermato 159(4):881-886. doi:10.1111/j.13652133.2008.08761.x

73. Nikolaou VA, Papadavid E, Katsambas A, Stratigos AJ, Marinos L, Anagnostou D, Antoniou C (2009) Clinical characteristics and course of $\mathrm{CD} 8+$ cytotoxic variant of mycosis fungoides: a case series of seven patients. Br J Dermatol 161(4):826-830. doi:10. 1111/j.1365-2133.2009.09301.x 
74. Rodriguez-Pinilla SM, Ortiz-Romero PL, Monsalvez V, Tomas IE, Almagro M, Sevilla A, Camacho G, Longo MI, Pulpillo A, Diaz-Perez JA, Montes-Moreno S, Castro Y, Echevarria B, Trebol I, Gonzalez C, Sanchez L, Otin AP, Requena L, Rodriguez-Peralto JL, Cerroni L, Piris MA (2013) TCR-gamma expression in primary cutaneous T-cell lymphomas. Am J Surg Pathol 37(3):375-384. doi:10.1097/PAS.0b013e318275d1a2

75. Michie SA, Abel EA, Hoppe RT, Warnke RA, Wood GS (1990) Discordant expression of antigens between intraepidermal and intradermal $\mathrm{T}$ cells in mycosis fungoides. Am J Pathol 137(6): $1447-1451$

76. Wood GS, Hong SR, Sasaki DT, Abel EA, Hoppe RT, Warnke RA, Morhenn VB (1990) Leu-8/CD7 antigen expression by CD3+ T cells: comparative analysis of skin and blood in mycosis fungoides/sezary syndrome relative to normal blood values. J Am Acad Dermatol 22(4):602-607

77. Alaibac M, Pigozzi B, Belloni-Fortina A, Michelotto A, Saponeri A, Peserico A (2003) CD7 expression in reactive and malignant human skin T-lymphocytes. Anticancer Res 23(3B):2707-2710

78. Florell SR, Cessna M, Lundell RB, Boucher KM, Bowen GM, Harris RM, Petersen MJ, Zone JJ, Tripp S, Perkins SL (2006) Usefulness (or lack thereof) of immunophenotyping in atypical cutaneous T-cell infiltrates. Am J Clin Pathol 125(5):727-736. doi:10.1309/3JK2-H6Y9-88NU-AY37

79. Stevens SR, Ke MS, Birol A, Terhune MH, Parry EJ, Ross C, Mostow EN, Gilliam AC, Cooper KD, Interdisciplinary Cutaneous Lymphoma P (2003) A simple clinical scoring system to improve the sensitivity and standardization of the diagnosis of mycosis fungoides type cutaneous T-cell lymphoma: logistic regression of clinical and laboratory data. B J Dermatol 149(3): 513-522

80. Wood GS, Abel EA, Hoppe RT, Warnke RA (1986) Leu-8 and Leu-9 antigen phenotypes: immunologic criteria for the distinction of mycosis fungoides from cutaneous inflammation. J Am Acad Dermatol 14(6):1006-1013

81. Izban KF, Hsi ED, Alkan S (1998) Immunohistochemical analysis of mycosis fungoides on paraffin-embedded tissue sections. Mod Pathol Off J United States and Canadian Acad Pathol Inc 11(10): 978-982

82. Nuckols JD, Shea CR, Horenstein MG, Burchette JL, Prieto VG (1999) Quantitation of intraepidermal T-cell subsets in formalinfixed, paraffin-embedded tissue helps in the diagnosis of mycosis fungoides. J Cutan Pathol 26(4):169-175

83. Zhang Y, Wang Y, Yu R, Huang Y, Su M, Xiao C, Martinka M, Dutz JP, Zhang X, Zheng Z, Zhou Y (2012) Molecular markers of early-stage mycosis fungoides. J Invest Dermatol 132(6):16981706. doi:10.1038/jid.2012.13

84. Raess PW, Bagg A (2012) The role of molecular pathology in the diagnosis of cutaneous lymphomas. Pathol Res Int 2012:913523. doi:10.1155/2012/913523

85. Alessi E, Coggi A, Venegoni L, Merlo V, Gianotti R (2005) The usefulness of clonality for the detection of cases clinically and/or histopathologically not recognized as cutaneous T-cell lymphoma. Br J Dermatol 153(2):368-371. doi:10.1111/j.1365-2133.2005. 06760.x

86. Bachelez H, Bioul L, Flageul B, Baccard M, Moulonguet-Michau I, Verola O, Morel P, Dubertret L, Sigaux F (1995) Detection of clonal T-cell receptor gamma gene rearrangements with the use of the polymerase chain reaction in cutaneous lesions of mycosis fungoides and sezary syndrome. Arch Dermatol 131(9):1027-1031

87. Cerroni L, Arzberger E, Ardigo M, Putz B, Kerl H (2000) Monoclonality of intraepidermal T lymphocytes in early mycosis fungoides detected by molecular analysis after laser-beam-based microdissection. J Invest Dermatol 114(6):1154-1157. doi:10. 1046/j.1523-1747.2000.00984.x
88. Curco N, Servitje O, Llucia M, Bertran J, Limon A, Carmona M, Romagosa V, Peyri J (1997) Genotypic analysis of cutaneous Tcell lymphoma: a comparative study of southern blot analysis with polymerase chain reaction amplification of the T-cell receptorgamma gene. Br J Dermatol 137(5):673-679

89. Kohler S, Jones CD, Warnke RA, Zehnder JL (2000) PCRheteroduplex analysis of T-cell receptor gamma gene rearrangement in paraffin-embedded skin biopsies. Am J Dermatopathol 22(4):321-327

90. Wood GS, Tung RM, Haeffner AC, Crooks CF, Liao S, Orozco R, Veelken H, Kadin ME, Koh H, Heald P et al (1994) Detection of clonal T-cell receptor gamma gene rearrangements in early mycosis fungoides/sezary syndrome by polymerase chain reaction and denaturing gradient gel electrophoresis (PCR/DGGE). J Invest Dermatol 103(1):34-41

91. Goeldel AL, Cornillet-Lefebvre P, Durlach A, Birembaut P, Bernard P, Nguyen P, Grange F (2010) T-cell receptor gamma gene rearrangement in cutaneous T-cell lymphoma: comparative study of polymerase chain reaction with denaturing gradient gel electrophoresis and GeneScan analysis. Br J Dermatol 162(4): 822-829. doi:10.1111/j.1365-2133.2009.09575.x

92. Lukowsky A, Muche JM, Mobs M, Assaf C, Humme D, Hummel M, Sterry W, Steinhoff M (2010) Evaluation of T-cell clonality in archival skin biopsy samples of cutaneous T-cell lymphomas using the biomed-2 PCR protocol. Diagnostic molecular pathology. Am J Surg Pathol B 19(2):70-77. doi:10.1097/PDM. 0b013e3181b2a1b7

93. Pfaltz K, Kerl K, Palmedo G, Kutzner H, Kempf W (2011) Clonality in sarcoidosis, granuloma annulare, and granulomatous mycosis fungoides. Am J Dermatopathol 33(7):659-662. doi:10. 1097/DAD.0b013e318222f906

94. Sandberg Y, Heule F, Lam K, Lugtenburg PJ, Wolvers-Tettero IL, van Dongen JJ, Langerak AW (2003) Molecular immunoglobulin/ $\mathrm{T}$ - cell receptor clonality analysis in cutaneous lymphoproliferations. Experience with the BIOMED-2 standardized polymerase chain reaction protocol. Haematologica 88(6):659-670

95. van Dongen JJ, Langerak AW, Bruggemann M, Evans PA, Hummel M, Lavender FL, Delabesse E, Davi F, Schuuring E, Garcia-Sanz R, van Krieken JH, Droese J, Gonzalez D, Bastard C, White HE, Spaargaren M, Gonzalez M, Parreira A, Smith JL, Morgan GJ, Kneba M, Macintyre EA (2003) Design and standardization of PCR primers and protocols for detection of clonal immunoglobulin and T-cell receptor gene recombinations in suspect lymphoproliferations: report of the BIOMED-2 concerted action BMH4-CT98-3936. Leukemia 17(12):2257-2317. doi:10. 1038/sj.leu.2403202

96. van Krieken JH, Langerak AW, Macintyre EA, Kneba M, Hodges E, Sanz RG, Morgan GJ, Parreira A, Molina TJ, Cabecadas J, Gaulard P, Jasani B, Garcia JF, Ott M, Hannsmann ML, Berger F, Hummel M, Davi F, Bruggemann M, Lavender FL, Schuuring E, Evans PA, White H, Salles G, Groenen PJ, Gameiro P, Pott C, Dongen JJ (2007) Improved reliability of lymphoma diagnostics via PCR-based clonality testing: report of the BIOMED-2 concerted action BHM4-CT98-3936. Leukemia 21(2):201-206. doi:10. 1038/sj.leu.2404467

97. Bruggemann M, White H, Gaulard P, Garcia-Sanz R, Gameiro P, Oeschger S, Jasani B, Ott M, Delsol G, Orfao A, Tiemann M, Herbst H, Langerak AW, Spaargaren M, Moreau E, Groenen PJ, Sambade C, Foroni L, Carter GI, Hummel M, Bastard C, Davi F, Delfau-Larue MH, Kneba M, van Dongen JJ, Beldjord K, Molina TJ (2007) Powerful strategy for polymerase chain reaction-based clonality assessment in T-cell malignancies report of the BIOMED-2 concerted action BHM4 CT98-3936. Leukemia 21(2):215-221. doi:10.1038/sj.leu.2404481

98. Ponti R, Quaglino P, Novelli M, Fierro MT, Comessatti A, Peroni A, Bonello L, Bernengo MG (2005) T-cell receptor gamma gene 
rearrangement by multiplex polymerase chain reaction/ heteroduplex analysis in patients with cutaneous T-cell lymphoma (mycosis fungoides/sezary syndrome) and benign inflammatory disease: correlation with clinical, histological and immunophenotypical findings. Br J Dermatol 153(3):565-573. doi:10.1111/j.1365-2133. 2005.06649.x

99. Dereure O, Levi E, Kadin ME (2000) T-cell clonality in pityriasis lichenoides et varioliformis acuta: a heteroduplex analysis of 20 cases. Arch Dermatol 136(12):1483-1486

100. Lukowsky A, Muche JM, Sterry W, Audring H (2000) Detection of expanded T cell clones in skin biopsy samples of patients with lichen sclerosus et atrophicus by $\mathrm{T}$ cell receptor-gamma polymerase chain reaction assays. J Invest Dermatol 115(2):254-259. doi: 10.1046/j.1523-1747.2000.00040.x

101. Schiller PI, Flaig MJ, Puchta U, Kind P, Sander CA (2000) Detection of clonal $\mathrm{T}$ cells in lichen planus. Arch Dermatol Res 292(11):568-569

102. Shieh S, Mikkola DL, Wood GS (2001) Differentiation and clonality of lesional lymphocytes in pityriasis lichenoides chronica. Arch Dermatol 137(3):305-308

103. Thurber SE, Zhang B, Kim YH, Schrijver I, Zehnder J, Kohler S (2007) T-cell clonality analysis in biopsy specimens from two different skin sites shows high specificity in the diagnosis of patients with suggested mycosis fungoides. J Am Acad Dermatol 57(5):782-790. doi:10.1016/j.jaad.2007.06.004

104. Ponti R, Fierro MT, Quaglino P, Lisa B, Paola F, Michela O, Paolo F, Comessatti A, Novelli M, Bernengo MG (2008) TCRgammachain gene rearrangement by PCR-based GeneScan: diagnostic accuracy improvement and clonal heterogeneity analysis in multiple cutaneous T-cell lymphoma samples. J Invest Dermatol 128(4):1030-1038. doi:10.1038/sj.jid.5701109

105. Vega F, Luthra R, Medeiros LJ, Dunmire V, Lee SJ, Duvic M, Jones D (2002) Clonal heterogeneity in mycosis fungoides and its relationship to clinical course. Blood 100(9):3369-3373. doi: 10.1182/blood.V100.9.3369

106. Nashan D, Faulhaber D, Stander S, Luger TA, Stadler R (2007) Mycosis fungoides: a dermatological masquerader. Br J Dermatol 156(1):1-10. doi:10.1111/j.1365-2133.2006.07526.x

107. Zackheim HS, McCalmont TH (2002) Mycosis fungoides: the great imitator. J Am Acad Dermatol 47(6):914-918. doi:10. 1067/mjd.2002.124696

108. LeBoit PE (2013) Simulators of cutaneous lymphoma: where should our efforts go? Am J Clin Pathol 139(4):414-417. doi: 10.1309/AJCP07TTPGFATGSO

109. Everett MA (1985) Early diagnosis of mycosis fungoides: vacuolar interface dermatitis. J Cutan Pathol 12(3-4):271-278

110. Toro JR, Sander CA, LeBoit PE (1997) Persistent pigmented purpuric dermatitis and mycosis fungoides: simulant, precursor, or both? a study by light microscopy and molecular methods. Am J Dermatopathol 19(2):108-118

111. Annessi G, Paradisi M, Angelo C, Perez M, Puddu P, Girolomoni G (2003) Annular lichenoid dermatitis of youth. J Am Acad Dermatol 49(6):1029-1036. doi:10.1016/S0190

112. Puddu P, Ferranti G, Frezzolini A, Colonna L, Cianchini G (1999) Pigmented purpura-like eruption as cutaneous sign of mycosis fungoides with autoimmune purpura. J Am Acad Dermatol 40(2 Pt 2):298-299

113. Crowson AN, Magro CM, Zahorchak R (1999) Atypical pigmentary purpura: a clinical, histopathologic, and genotypic study. Hum Pathol 30(9):1004-1012

114. Wolf R, Kahane E, Sandbank M (1985) Mycosis fungoides-like lesions associated with phenytoin therapy. Arch Dermatol 121(9): $1181-1182$

115. Rijlaarsdam U, Scheffer E, Meijer CJ, Kruyswijk MR, Willemze R (1991) Mycosis fungoides-like lesions associated with phenytoin and carbamazepine therapy. J Am Acad Dermatol 24(2 Pt 1): 216-220

116. Furness PN, Goodfield MJ, MacLennan KA, Stevens A, Millard LG (1986) Severe cutaneous reactions to captopril and enalapril; histological study and comparison with early mycosis fungoides. J Clin Pathol 39(8):902-907

117. Crowson AN, Magro CM (1995) Antidepressant therapy. A possible cause of atypical cutaneous lymphoid hyperplasia. Arch Dermatol 131(8):925-929

118. Magro CM, Crowson AN (1995) Drugs with antihistaminic properties as a cause of atypical cutaneous lymphoid hyperplasia. J Am Acad Dermatol 32(3):419-428

119. Clark SH, Duvic M, Prieto VG (2003) Mycosis fungoides-like reaction in a patient treated with Gleevec. J Cutan Pathol 30(4): 279-281

120. Magro CM, Crowson AN (1996) Drug-induced immune dysregulation as a cause of atypical cutaneous lymphoid infiltrates: a hypothesis. Hum Pathol 27(2):125-132

121. El-Darouti MA, Marzouk SA, Azzam O, Fawzi MM, AbdelHalim MR, Zayed AA, Leheta TM (2006) Vitiligo vs. hypopigmented mycosis fungoides (histopathological and immunohistochemical study, univariate analysis). Eur J Dermato EJD 16(1):17-22

122. Saggini A, Gulia A, Argenyi Z, Fink-Puches R, Lissia A, Magana M, Requena L, Simonitsch I, Cerroni L (2010) A variant of lymphomatoid papulosis simulating primary cutaneous aggressive epidermotropic CD8+ cytotoxic T-cell lymphoma. Description of 9 cases. Am J Surg Pathol 34(8):1168-1175. doi:10.1097/PAS. 0b013e3181e75356 